\title{
Genetic Variability, Correlation and Path Coefficient Analysis in the Indian Mustard (Brassica juncea L. Czern and Coss) Varieties Grown in Chitrakoot, India
}

\author{
Sandeep Dawar, Navin Kumar* and S.P. Mishra \\ Department of Crop Science, MGCGV, Chitrakoot, Satna MP, India \\ *Corresponding author
}

\begin{abstract}
A B S T R A C T
Keywords

Genotypes.

Heritability,

Variability,

Breeding

Article Info

Accepted:

10 February 2018

Available Online:

10 March 2018

The present research was carried out to determine the selection criteria for yield improvement in selected genotypes of Indian mustard. Thirty genotypes were sown at MGCGV farm Chitrakoot to evaluate the mean and component of variability, correlation and path analysis for yield and various yield components. The correlation coefficient of the seed yield per plant (g.) had significant and positive correlation with plant height; number of primary branch, total no. of siliqua per plant and 1000-seed weight at genotypic level. Path coefficient analysis revealed that, the highest positive direct effect on seed yield (g) was exhibited by total no. of siliqua per plant, plant height, 1000-seed weight, Number of primary branches and number of seed per siliqua had direct positive contribution towards seed yield per plant. For mustard breeding seed per plant is variable with maximum potential of selection for seed yield improvement because this traits possessed high heritability significant positive correlation and maximum positive direct effects with yield.

\section{Introduction}

Mustard belongs to the family of cruciferae. Indian mustard (B. juncea $2 \mathrm{n}=4 \mathrm{x}=36$ ) and yellow sarson (B. campestris) are the important species largely grown as oilseed crop in subtropical and tropical countries.

Indian mustard (B. juncea (Linn) Czern and Coss) popularly known as rai, raya or laha is one of the most important oil seed crops of the country and it occupies considerably large acerage among the Brassica group of oil seed crops. It is estimated the total production of mustard seed in India about more than 72.82 lakh tones significantly. The state of M.P

stand $3^{\text {rd }}$ largest mustard producing state in India. (www.thedailyrecords.com).

Information on the nature and magnitude of variability present in the existing material and association among the various morphological characters is a pre-requisite for any breeding programme to be initiated by the local breeder for high yields. However, seed yield, a complex character is usually controlled by non-additive gene actions and it is not only influenced by a number of other morphological characters which are governed by a large number of genes, but also environment to a great extent. Thereby, the heritable variation creates difficulty in a
\end{abstract}


selection programme. Therefore, it is necessary to partition the overall variability into heritable and non-heritable components which enables the breeders to adopt suitable breeding procedure for further improvement of genetic stocks. Mutual association of plant characters which is determined by correlation coefficient is useful for indirect selection. This further permits evaluation of relative influence of various components of yield. The path coefficient analysis developed by Wright (1921) is helpful in partitioning the correlation coefficient into direct and indirect effects and in the assessment of relative contribution of each component to the yield.

\section{Materials and Methods}

The Experiment was conducted to evaluate the thirty genotypes/varieties of mustard under normal soil and rain fed condition. The experiment was laid out following Randomized Block Design (RBD) with three replications during Rabi 2015 at Agriculture Farm, Nana Ji Deshmukh New Agriculture campus, Mahatma Gandhi Chitrakoot Gramodaya Vishwavidyalaya, Chitrakoot, Satna (M. P.) The experiment was sown on $04^{\text {th }}$, November; 2015. Each treatment was grown in $3 \mathrm{~m}$ long single row plot spaced 45 $\mathrm{cm}$ apart. The plant to plant distance was maintained $30 \mathrm{~cm}$ by thinning. Recommended agronomic practices and plant protection measures were adopted to raise a good crop.

Five competitive plants from each plot were randomly selected for recording of observations on nine characters. Average of the data from the sampled plants of each plot in respect of different characters was used for various statistical analyses. The data were recorded for the following characters. Data collected on traits viz., Days to 50\% flowering, Number of primary branches, Total number of siliqua per plant, Number of silique on main stem, Siliqua Length $(\mathrm{cm})$, Number of seeds per siliqua, Plant height $(\mathrm{cm})$, 1000seed weight (g), Seed yield per plant(g).The experimental data were subjected to statistical analysis as following standard statistical procedure described Panse and Sukhatme (1967) to assess component of variance and coefficient of variation. Correlation coefficient between different characters were calculated as per Miller et al., (1958), path coefficient analysis was done as suggested by Dewey and Lu (1959).

\section{Results and Discussion}

Analysis of variance for the design of the experiment indicated highly significant differences for all the characters viz. day to $50 \%$ flowering, no. of primary branches per plant, total no. of silique per plant, number of silique on main stem, siliqua length $(\mathrm{cm})$, no. of seeds per siliqua, plant height $(\mathrm{cm}), 1000$ seed weight $(\mathrm{g})$ and seed yield per plant $(\mathrm{g})$. Non-significant differences due to replications and error were observed for all nine characters (Table 1).

Phenotypic coefficients of variation were higher than genotypic coefficient of variation for all the characters, the data depicted in Table 2. The Seed yield per plant were ranged from $11.60 \mathrm{~g}$ (MCN-08) to $25.73 \mathrm{~g}$ (MCN-07) while the grand mean was $17.64 \mathrm{gm}$. Seed yield per plant exhibited highest values of phenotypic (26.59) and genotypic (21.62) coefficient of variation, respectively for this character.

High heritability estimate were found for plant height, siliqua length, total no. of siliqua per plant, days to $50 \%$ flowering and 1000-seed weight. The Moderate heritability estimates were found for no. of seeds per siliqua, no. of siliqua on main stem and seed yield per plant, while low heritability estimates was found for no. of branches per plant. Similar results were reported by Gupta and Singh (1998) for 1000- 
seed weight and yield per plant, Husain et al., (1998) for number of seeds per siliqua. Kumar et al., (2005), Mahto and Haider (2013) Lodhi et al., (2014) for seed yield, number of secondary branches/ plant, 1000- seed weight, Bind et al., (2014) for 1000 seed weight and Rashid et al., (2014) for seed yield.

The expected genetic advance in per cent of mean ranged from 6.70 per cent for days to $50 \%$ flowering to 39.74 per cent for 1000 -seed weight, whereas, total no. of silique per plant, seed yield per plant, plant height, no. of siliqua on main stem, siliqua length, no. of seeds per siliqua and no. of primary branches showed genetic advance in per cent of mean in decreasing order (Table 2).

The high heritability coupled with high genetic advance was found with total no. of siliqua per plant, plant height and no. of siliqua on main stem, while high heritability coupled with low genetic advance were found in remaining characters.

In earlier studies, high GS\% coupled with high $h^{2} b$ has been reported by (Choudhury and Goswami (1991), Comstock and Moll (1963), Dang et al., 2000, Das et al., (1998), Dhillon et al., (2001), Eberhart et al., (1966) and Mahto and Haider (2013).

The seed yield per plant (g.) showed significant and positive correlation with plant height (0.297); number of primary branch (0.261), total no. of siliqua per plant (0.226) and 1000-seed weight at genotypic level. At phenotypic level plant height (0.242); total no. of siliqua per plant (0.163), 1000-seed weight and number of primary branch (0.122) exhibited significant and positive correlation with seed yield per plant.

Among other correlations, 1000- seed weight showed positive and highly significant with siliqua length (0.453) and days to50\% flowering (0.410), while number of seeds per siliqua (-0.576) exhibited negative correlation with 1000-seed weight at genotypic level.

At genotypic level, the positively correlated days to $50 \%$ flowering (0.308), siliqua length (0.256) and number of primary branches (0.247) with plant height. The Total no of siliqua per plant (0.196) with siliqua length; Total no of siliqua per plant $(0.671)$ with no. of siliqua on main stem. While negative correlation was exhibited by no. of primary branches $(-0.497)$ with no. of siliqua on main stem; no. of primary branches $(-0.351)$ with total no of siliqua per plant; days to $50 \%$ flowering (-0.368) and siliqua length (-0.273) with no. of seeds per siliqua.

At phenotypic level, correlation coefficient 1000- seed weight showed positive and highly significant with siliqua length (0.406) and days to50\% flowering (0.319), while number of seeds per siliqua (-0.402) exhibited negative correlation with 1000 -seed weight at genotypic level.

Among other characters, the positive correlation coefficient showed for siliqua length (0.239); days to $50 \%$ flowering (0.277) with plant height; total number of siliqua per plant (0.506) with no. of siliqua on main stem. Exhibited significant and positive correlation at phenotypic level.

Whereas days to $50 \%$ flowering $(-0.332)$, and siliqua length $(-0.208)$ with no. of seeds per siliqua; no. of primary branches $(-0.227)$ with no. of siliqua on main stem exerted negative and significant correlation at phenotypic level (Table 3).

The results are in agreement with the result of Kashyap and Mishra (2004), Mishra (2012), Rashid et al., (2014) and Lodhi et al., (2014) for positive and significant correlation with number of primary branches/ plant, number of secondary branches/ plant, primary. 
Table.1 Analysis of variance for nine quantitative characters in Indian mustard

\begin{tabular}{|c|c|c|c|c|c|c|c|c|c|c|c|}
\hline \multicolumn{2}{|c|}{ Source of variation } & df & $\begin{array}{l}\text { Day to } 50 \\
\% \\
\text { flowering }\end{array}$ & $\begin{array}{l}\text { No. of } \\
\text { primary } \\
\text { branches } \\
\text { per plant }\end{array}$ & $\begin{array}{l}\text { Total No. } \\
\text { of silique } \\
\text { per plant }\end{array}$ & $\begin{array}{l}\text { No of } \\
\text { Silique on } \\
\text { main stem }\end{array}$ & $\begin{array}{l}\text { Siliqua } \\
\text { length } \\
(\mathrm{cm})\end{array}$ & $\begin{array}{l}\text { No. of seeds } \\
\text { per siliqua }\end{array}$ & $\begin{array}{l}\text { Plant height } \\
(\mathrm{cm} .)\end{array}$ & $\begin{array}{l}1000 \\
\text { seed } \\
\text { weight } \\
\text { (g) }\end{array}$ & $\begin{array}{l}\text { Seed yield } \\
\text { per } \\
\text { plant(g) }\end{array}$ \\
\hline \multirow{3}{*}{$\begin{array}{l}\text { Mean } \\
\text { sum of } \\
\text { square }\end{array}$} & Replication & 2 & 0.77 & 0.56 & 236.25 & 15.27 & 0 & 0.68 & 9.19 & 0.26 & 5.14 \\
\hline & Treatment & 29 & $14.84 * * *$ & $0.84 * * *$ & $2564.9 * * *$ & $179.31 * * *$ & $1.43^{* * *}$ & $11.18 * * *$ & $2183.99 * * *$ & $5.27 * * *$ & $51.11 * * *$ \\
\hline & Error & 58 & 0.9 & 0.27 & 92.98 & 23.02 & 0.04 & 1.39 & 9.6 & 0.49 & 7.46 \\
\hline
\end{tabular}

* Significant at 5\% Probability level **Significant at $1 \%$ Probability level

Table.2 Mean, range, GCV, PCV. Heritability (\%) in broad sense, genetic advance and genetic advance in percent of mean for 09 quantitative characters in Indian mustard

\begin{tabular}{|c|c|c|c|c|c|c|c|c|c|}
\hline $\begin{array}{l}\text { S. } \\
\mathbf{N}\end{array}$ & Characters/Traits & $\begin{array}{l}\text { Grand Mean } \\
(X)+\text { SE }\end{array}$ & Range & & $\begin{array}{l}\text { Coeffi } \\
\text { variat }\end{array}$ & ent of & $\begin{array}{l}\text { Heritabil } \\
\text { ity }\end{array}$ & $\begin{array}{l}\text { Genetic } \\
\text { advance }\end{array}$ & $\begin{array}{l}\text { Genetic } \\
\text { advance in }\end{array}$ \\
\hline o. & & & Min & $\operatorname{Max}$ & GCV & PCV & $\begin{array}{l}\text { (broad } \\
\text { sense) }\end{array}$ & & $\begin{array}{l}\text { percent of } \\
\text { mean }\end{array}$ \\
\hline 1 & Day to $50 \%$ flowering & $60.65 \pm 0.55$ & 56.83 & 64.8 & 3.55 & 3.88 & 83.70 & 4.06 & 6.70 \\
\hline 2 & $\begin{array}{l}\text { No. of primary } \\
\text { branches per plant }\end{array}$ & $4.60 \pm 0.30$ & 3.73 & 6.07 & 9.43 & 14.76 & 40.82 & 0.57 & 12.41 \\
\hline 3 & $\begin{array}{l}\text { Total No. of silique per } \\
\text { plant }\end{array}$ & $146.88 \pm 5.57$ & 94.6 & 199.47 & 19.54 & 20.62 & 89.86 & 56.05 & 38.16 \\
\hline 4 & $\begin{array}{l}\text { No of Silique on main } \\
\text { stem }\end{array}$ & $35.13 \pm 2.77$ & 23.07 & 51.73 & 20.55 & 24.67 & 69.36 & 12.38 & 35.25 \\
\hline 5 & Siliqua length (cm) & $4.43 \pm 0.12$ & 3.63 & 6.47 & 15.37 & 16.04 & 91.76 & 1.34 & 30.33 \\
\hline 6 & $\begin{array}{l}\text { No. of seeds per } \\
\text { siliqua }\end{array}$ & $12.39 \pm 0.68$ & 8.43 & 16.73 & 14.58 & 17.41 & 70.17 & 3.12 & 25.16 \\
\hline 7 & Plant height (cm.) & $152.05 \pm 1.79$ & 76.47 & 186.27 & 17.54 & 17.66 & 98.67 & 54.58 & 35.90 \\
\hline 8 & 1000 seed weight $(\mathrm{g})$ & $5.71 \pm 0.41$ & 4.33 & 8.47 & 22.08 & 25.27 & 76.35 & 2.27 & 39.74 \\
\hline 9 & Seed yield per plant $(\mathrm{g})$ & $17.64 \pm 1.58$ & 11.6 & 25.73 & 21.62 & 26.59 & 66.12 & 6.39 & 36.22 \\
\hline
\end{tabular}


Table.3 Estimates of genotypic correlations and phenotypic correlation for different quantitative characters in Indian mustard

\begin{tabular}{|c|c|c|c|c|c|c|c|c|c|c|c|}
\hline Sr.No. & \multicolumn{2}{|c|}{ Character } & $\begin{array}{c}\text { Day to } 50 \\
\% \\
\text { flowering }\end{array}$ & $\begin{array}{c}\text { No. of } \\
\text { primary } \\
\text { branches } \\
\text { / plant }\end{array}$ & $\begin{array}{l}\text { Total } \\
\text { No. of } \\
\text { silique } \\
\text { /plant }\end{array}$ & $\begin{array}{l}\text { No of } \\
\text { Silique } \\
\text { on } \\
\text { main } \\
\text { stem }\end{array}$ & $\begin{array}{c}\text { Siliqua } \\
\text { length } \\
\text { (cm) }\end{array}$ & $\begin{array}{l}\text { No. of } \\
\text { seeds / } \\
\text { siliqua }\end{array}$ & $\begin{array}{c}\text { Plant } \\
\text { height } \\
(\mathrm{cm} .)\end{array}$ & $\begin{array}{c}1000 \\
\text { seed } \\
\text { weight } \\
(\mathrm{g})\end{array}$ & $\begin{array}{l}\text { Seed yield } \\
\text { / plant(g) }\end{array}$ \\
\hline \multirow[t]{2}{*}{1.} & \multirow{2}{*}{$\begin{array}{l}\text { Day to } 50 \% \\
\text { flowering }\end{array}$} & $r_{g}$ & 1 & -0.020 & -0.021 & -0.086 & 0.169 & -0.368 & 0.308 & 0.410 & 0.075 \\
\hline & & $r_{p}$ & 1 & 0.009 & -0.023 & -0.053 & 0.126 & $-0.332 * *$ & $0.277 * *$ & $0.319 * *$ & 0.063 \\
\hline \multirow[t]{2}{*}{2.} & \multirow{2}{*}{$\begin{array}{c}\text { No. of } \\
\text { primary } \\
\text { branches per } \\
\text { plant }\end{array}$} & $r_{g}$ & & 1 & -0351 & -0.497 & 0.166 & 0.098 & 0.247 & -0.031 & 0.261 \\
\hline & & $r_{p}$ & & 1 & -0.192 & $-0.227^{*}$ & 0.093 & 0.129 & 0.140 & -0.061 & 0.122 \\
\hline \multirow[t]{2}{*}{3.} & \multirow{2}{*}{$\begin{array}{l}\text { Total No. of } \\
\text { silique per } \\
\text { plant }\end{array}$} & $r_{g}$ & & & 1 & 0.671 & 0.196 & -0.020 & -0.129 & 0.092 & 0.226 \\
\hline & & $r_{p}$ & & & 1 & $0.506^{* *}$ & 0.191 & -0.019 & -0.126 & 0.066 & 0.167 \\
\hline \multirow[t]{2}{*}{4.} & \multirow{2}{*}{$\begin{array}{l}\text { No of Silique } \\
\text { on main stem }\end{array}$} & $r_{g}$ & & & & 1 & -0.173 & 0.051 & -0.013 & -0.216 & 0.026 \\
\hline & & $r_{p}$ & & & & 1 & -0.124 & 0.003 & -0.003 & -0.103 & 0.005 \\
\hline \multirow[t]{2}{*}{5.} & \multirow{2}{*}{$\begin{array}{c}\text { Siliqua } \\
\text { length }(\mathrm{cm})\end{array}$} & $r_{g}$ & & & & & 1 & -0.273 & 0.256 & 0.453 & 0.106 \\
\hline & & $r_{p}$ & & & & & 1 & $-0.208^{*}$ & 0.239 & $0.406^{* *}$ & 0.105 \\
\hline \multirow[t]{2}{*}{6.} & \multirow{2}{*}{$\begin{array}{l}\text { No. of seeds } \\
\text { per siliqua }\end{array}$} & $r_{g}$ & & & & & & 1 & -0.162 & -0.576 & 0.54 \\
\hline & & $r_{p}$ & & & & & & 1 & -0.137 & $-0.402 * *$ & 0.039 \\
\hline \multirow[t]{3}{*}{7.} & \multirow{3}{*}{$\begin{array}{l}\text { Plant height } \\
\quad(\mathrm{cm} .)\end{array}$} & $r_{g}$ & & & & & & & 1 & 0.195 & 0.297 \\
\hline & & & & & & & & & & & \\
\hline & & $r_{p}$ & & & & & & & 1 & 0.162 & $0.242 *$ \\
\hline \multirow[t]{2}{*}{8.} & \multirow{2}{*}{$\begin{array}{l}1000 \text { seed } \\
\text { weight }(\mathrm{g})\end{array}$} & $r_{g}$ & & & & & & & & 1 & 0.203 \\
\hline & & $r_{p}$ & & & & & & & & 1 & 0.163 \\
\hline \multirow[t]{3}{*}{9.} & \multirow{3}{*}{$\begin{array}{l}\text { Seed yield } \\
\text { per plant }(\mathrm{g})\end{array}$} & $r_{g}$ & & & & & & & & & 1 \\
\hline & & & & & & & & & & & \\
\hline & & $r_{p}$ & & & & & & & & & 1 \\
\hline
\end{tabular}

*Significant at $5 \%$ probability level; **Significant at $1 \%$ probability level. 


\begin{tabular}{|c|c|c|c|c|c|c|c|c|c|}
\hline No & Characters & $\begin{array}{l}\text { Day to } 50 \\
\% \\
\text { flowering }\end{array}$ & $\begin{array}{l}\text { No. of } \\
\text { primary } \\
\text { branches } \\
\text { per } \\
\text { plant }\end{array}$ & $\begin{array}{l}\text { Total } \\
\text { No. of } \\
\text { silique } \\
\text { per } \\
\text { plant }\end{array}$ & $\begin{array}{l}\text { No of } \\
\text { Silique } \\
\text { on } \\
\text { main } \\
\text { stem }\end{array}$ & $\begin{array}{l}\text { Siliqua } \\
\text { length } \\
\text { (cm) }\end{array}$ & $\begin{array}{l}\text { No. of } \\
\text { seeds } \\
\text { per } \\
\text { siliqua }\end{array}$ & $\begin{array}{l}\text { Plant } \\
\text { height } \\
\text { (cm.) }\end{array}$ & $\begin{array}{l}1000 \\
\text { seed } \\
\text { weight( } \\
\text { g) }\end{array}$ \\
\hline 1 & $\begin{array}{l}\text { Day to } 50 \% \\
\text { flowering }\end{array}$ & -0.033 & 0.001 & 0.001 & 0.003 & -0.006 & 0.012 & -0.010 & -0.014 \\
\hline 2 & $\begin{array}{l}\text { No. of primary } \\
\text { branches per plant }\end{array}$ & -0.006 & 0.319 & -0.112 & -0.159 & 0.053 & 0.031 & 0.079 & -0.010 \\
\hline 3 & $\begin{array}{l}\text { Total No. of } \\
\text { silique per plant }\end{array}$ & -0.010 & -0.166 & 0.473 & 0.317 & 0.093 & -0.009 & -0.061 & 0.043 \\
\hline 4 & $\begin{array}{l}\text { No of Silique on } \\
\text { main stem }\end{array}$ & 0.010 & 0.056 & -0.076 & -0.114 & 0.020 & -0.006 & 0.001 & 0.025 \\
\hline 5 & $\begin{array}{l}\text { Siliqua length } \\
(\mathrm{cm})\end{array}$ & -0.038 & -0.037 & -0.043 & 0.038 & -0.222 & 0.061 & -0.057 & -0.100 \\
\hline 6 & $\begin{array}{l}\text { No. of seeds per } \\
\text { siliqua }\end{array}$ & -0.072 & 0.019 & -0.004 & 0.010 & -0.053 & 0.195 & -0.032 & -0.112 \\
\hline 7 & Plant height (cm.) & 0.097 & 0.078 & -0.041 & -0.004 & 0.081 & -0.051 & 0.316 & 0.062 \\
\hline 8 & $\begin{array}{l}1000 \quad \text { seed } \\
\text { weight }(\mathrm{g})\end{array}$ & 0.127 & -0.010 & 0.028 & -0.067 & 0.140 & -0.178 & 0.060 & 0.309 \\
\hline 9 & $\begin{array}{l}\text { Seed yield per } \\
\operatorname{plant}(\mathrm{g})\end{array}$ & 0.075 & 0.261 & 0.226 & 0.026 & 0.106 & 0.054 & 0.297 & 0.203 \\
\hline & Partial R² & -0.002 & 0.083 & 0.107 & -0.003 & -0.023 & 0.011 & 0.094 & 0.063 \\
\hline
\end{tabular}

Table.5 Direct and indirect effects for different characters on seed yield per plant at phenotypic level in Indian Mustard

\begin{tabular}{|c|c|c|c|c|c|c|c|c|c|}
\hline No & Characters & $\begin{array}{l}\text { Day to } 50 \\
\% \\
\text { flowering }\end{array}$ & $\begin{array}{l}\text { No. of } \\
\text { primary } \\
\text { branches } \\
\text { per plant }\end{array}$ & $\begin{array}{l}\text { Total } \\
\text { No. of } \\
\text { silique } \\
\text { per } \\
\text { plant }\end{array}$ & $\begin{array}{l}\text { No of } \\
\text { Silique } \\
\text { on } \\
\text { main } \\
\text { stem }\end{array}$ & $\begin{array}{l}\text { Siliqua } \\
\text { length } \\
(\mathrm{cm})\end{array}$ & $\begin{array}{l}\text { No. of } \\
\text { seeds } \\
\text { per } \\
\text { siliqua }\end{array}$ & $\begin{array}{l}\text { Plant } \\
\text { height } \\
(\mathrm{cm} .)\end{array}$ & $\begin{array}{l}1000 \text { seed } \\
\text { weight }(\mathrm{g})\end{array}$ \\
\hline 1 & $\begin{array}{l}\text { Day to } 50 \quad \% \\
\text { flowering }\end{array}$ & -0.023 & 0.000 & 0.001 & 0.001 & -0.003 & 0.008 & -0.007 & -0.007 \\
\hline 2 & $\begin{array}{l}\text { No. of primary } \\
\text { branches per plant }\end{array}$ & 0.001 & 0.120 & -0.023 & -0.027 & 0.011 & 0.016 & 0.017 & -0.007 \\
\hline 3 & $\begin{array}{l}\text { Total No. of silique } \\
\text { per plant }\end{array}$ & -0.007 & -0.054 & 0.283 & 0.143 & 0.054 & -0.005 & -0.036 & 0.019 \\
\hline 4 & $\begin{array}{l}\text { No of Silique on } \\
\text { main stem }\end{array}$ & 0.005 & 0.023 & -0.052 & -0.103 & 0.013 & 0.000 & 0.000 & 0.011 \\
\hline 5 & Siliqua length $(\mathrm{cm})$ & -0.011 & -0.008 & -0.017 & 0.011 & -0.088 & 0.018 & -0.021 & -0.036 \\
\hline 6 & $\begin{array}{l}\text { No. of seeds per } \\
\text { siliqua }\end{array}$ & -0.038 & 0.015 & -0.002 & 0.000 & -0.024 & 0.115 & -0.016 & -0.046 \\
\hline 7 & Plant height (cm.) & 0.076 & 0.038 & -0.035 & -0.001 & 0.066 & -0.038 & 0.274 & 0.044 \\
\hline \multirow[t]{3}{*}{8} & $\begin{array}{ll}1000 & \text { seed } \\
\text { weight }(g) & \end{array}$ & 0.060 & -0.011 & 0.012 & -0.019 & 0.076 & -0.075 & 0.030 & 0.187 \\
\hline & $\begin{array}{l}\text { Seed yield per } \\
\operatorname{plant(g)}\end{array}$ & 0.063 & 0.122 & 0.167 & 0.005 & 0.105 & 0.039 & 0.242 & 0.163 \\
\hline & Partial R ${ }^{2}$ & -0.001 & 0.015 & 0.047 & -0.001 & -0.009 & 0.004 & 0.066 & 0.031 \\
\hline
\end{tabular}


Path coefficient analysis revealed that, the highest positive direct effect on seed yield (g) was exhibited by total no. of siliqua per plant (0.473), Number of primary branches (0.319), plant height (0.316), 1000-seed weight (0.309) and number of seed per siliqua (0.195). Negative direct effect was recorded in siliqua length $(-0.222)$, no. of siliqua on main stem (-0.114) and days to $50 \%$ flowering (-0.0.33) contributed substantial negative direct effects on seed yield at genotypic level (Table 4).

At phenotypic level, path coefficient analysis revealed that, the highest positive direct effect on seed yield ( $\mathrm{g}$ ) was exhibited by total no. of siliqua per plant (0.283), plant height (0.274), 1000 -sed weight (0.187), Number of primary branches (0.120) and number of seed per siliqua (0.115). Negative direct effect was recorded in no. of siliqua on main stem ($0.103)$, siliqua length $(-0.088)$ and days to $50 \%$ flowering $(-0.023) \quad$ contributed substantial negative direct effects on seed yield (Table 5).

Number of seeds per siliqua (-0.112), siliqua length (-0.100) via 1000-seed weight; 1000seed weight $(-0.178)$ via no. of seeds per siliqua ; no. of primary branches (-0.159) via no. of siliqua on main stem; no. of primary branches (-0.112) via total no. of siliqua per plant; exerted substantial negative indirect effects on seed yield, while total no. of siliqua per plant (0.317) via no. of siliqua on main stem; 1000-seed weight $(0.140)$ via siliqua length; 1000-seed weight $(0.127)$ and plant height (0.097) via days to $50 \%$ flowering exerted substantial positive indirect effects on seed yield at genotypic level.

Total number of siliqua per plant (0.143) via no. of siliqua on main stem; 1000-seed weight; plant height (0.076), plant height (0.076), days to $50 \%$ flowering, 1000-seed weight (0.076), plant height (0.075) via siliqua length; exerted substantial positive indirect effects on seed yield while 1000-seed weight (-0.075) via no. of seeds per siliqua exhibited negative indirect effect on seed yield at phenotypic level.

This result was found in accordance with the results reported by Masood et al., (1999) for seeds per pod; Sheikh et al., (1999) for 1000seed weight; Sial (2003) for plant height; Kashyap and Mishra (2004) for number of seeds per siliqua Anand et al., (2010), Sharma et al., (2010). Lodhi et al., (2014) for positive direct effect on seed yield/ plant, Rashid et al., (2014) for direct positive contribution of seeds pod-1 toward seed yield.

The remaining estimates of the indirect effects in the present analysis were too low to be considered important. The estimate of residual factors phenotypic (0.9208) and genotypic (0.8197) was high indicating that some of characters viz. total no. of siliqua per plant, Number of primary branches, plant height, 1000-seed weight and number of seed per siliqua affecting seed yield have to be included in the present study for further improvement programme of mustard with most suitable varieties viz- $\mathrm{MCN}-07$ and ALBELL varieties for this rainfed area.

\section{References}

Chowdhury, P.R. and Goswami, C.D. (1991). Genetic variability studies in Indian mustard (Brassica juncea (L.) Czern and Coss.). Environ. Ecol. 9: 10031006.

Comstock, R.E. and Moll, R.H. (1963). "Genotype-environment interactions". In: statistical genetics and plant breeding. Nas-nrc, publ., 82: 164-196.

Dang, J.K., Sangwan, M.S., Mihta, N and Kaushil, C.D. (2000). Multiple disease resistance against four fungal foliar 
diseases of rapeseed-mustard. Indian Phytopath. 53 (4): 455-458.

Das. K; Barua, P.K. and Hazarika, C.N. (1998). Genetic variability and correlation in Indian mustard. J. Agric. Sci. Soc. North -East India. 11: 262264.

Dhillon, S.S., Brar, K.S., Singh, K. and Raheja, R.K. (2001). G x E interaction and stability of elite strains in Indian mustard. Crop Improvement. 28: 1, 8994.

Eberhart, S.A. and Russell, W.L. (1966). Stability parameters for comparing varieties. Crop Sci., 6: 36-40.

Hussain, S.M., Sarma, B.K. and Mahajan, V. (1996). Stability analysis of seed yield in rapeseed-mustard under Nagaland conditions. Journal of Hill Research. 9: $1,161-162$.

Johnson, H.M., Robinson, H.F. and Caomstock, R.E. (1955). Estimates of genetic and environmental variability in soybean. Agron. J., 47: 314-318.
Lodhi, Balvir, Thakral, NK, Avtar, Ram and Singh, Amit (2014) Genetic variability, association and path analysis in Indian mustard (Brassica juncea) Journal of Oilseed, Brassica, 5(1) :26-31.

Mahto and Haider (2013) genetic divergence and stability analysis in Indian mustard (Brassica juncea L. Czernj \& Cosson) Genetic Resource.

Panse, V.G. and Sukhatme, P.V. (1978). Statistical Methods for Agricultural Workers, III ${ }^{\text {rd }}$ edition, ICAR, New Delhi.

Rashid, Tahira, Abdul, Khan, Muhammad Ayub, Amjad Muhammad (2014).Seed Yield Improvement in Mustard [Brassica juncea (L.) Czern \& Coss] via Genetic Parameters; Heritability, Genetic Advance, Correlation and Path Coefficient Analysis. International Journal of Agriculture Innovations and Research, 3 (3): 727-731.

www.thedailyrecords.com.

\section{How to cite this article:}

Sandeep Dawar, Navin Kumar and Mishra, S.P. 2018. Genetic Variability, Correlation and Path Coefficient Analysis in the Indian Mustard (Brassica juncea L. Czern and Coss) Varieties Grown in Chitrakoot. Int.J.Curr.Microbiol.App.Sci. 7(03): 883-890.

doi: https://doi.org/10.20546/ijcmas.2018.703.103 